\title{
Effect of Nitrates, Thiocyanates and Selenium on the Iron and lodine Status of Postpartum Women
}

\author{
Anelia V. Bivolarska ${ }^{1}$, Ana I. Maneva ${ }^{1}$, Penka D. Gatseva ${ }^{2}$, Mariana N. Katsarova ${ }^{1}$ \\ ${ }^{1}$ Department of Chemistry and Biochemistry, Faculty of Pharmacy, Medical University of Plovdiv, Plovdiv, Bulgaria \\ ${ }^{2}$ Department of Hygiene and Eco-medicine, Faculty of Public Health, Medical University of Plovdiv, Plovdiv, Bulgaria
}

\author{
Correspondence: A. Bivolarska, \\ Department of Chemistry and \\ Biochemistry, Faculty of Pharmacy, \\ Medical University of Plovdiv, 15A \\ Vassil Aprilov Blvd., 4002 Plovdiv, \\ Bulgaria \\ E-mail: anellena@abv.bg \\ Tel. +35932602545, 0887611786
}

Received: 4 Nov 2015

Accepted: 31 May 2016

Published Online: 8 Aug 2016

Published: 30 Sep 2016

Key words: iodine; nitrates, thiocyanates, iron status, iodine status

Citation: Bivolarska AV, Maneva Al, Gatseva PD, Katsarova MN. Effect of Nitrates, Thiocyanates and Selenium on the Iron and lodine Status of Postpartum Women.

Folia Medica 2016;58(3);188-194 doi: 10.1515/folmed-2016-0024
Aim: To find correlations between high thiocyanate and nitrate levels and low selenium levels and the indicators of the iodine and iron status of postpartum women.

Materials and methods: The study included 41 mothers aged $26.4 \pm 5.9 \mathrm{yrs}$ from Asenovgrad and nearby villages. Urinary iodine was determined by the SandellKolthoff reaction and thiocyanate - by the interaction of these ions with acidic solution of $\mathrm{KMnO}_{4}$; for serum nitrates we used the colorimetric method; serum selenium was assessed by electro-thermal atomic-absorption spectrophotometry; thyroxin (FT4), the thyroid stimulating hormone (TSH), serum ferritin (SF), and serum transferrin receptor (sTfR) were determined using ELISA; $\mathrm{Hb}$ levels were determined by hematology analyzer.

Results: Assessing the iodine status, we found a negative correlation between the levels of iodine and thiocyanates in urine $(R=-0.717, p<0.0001)$, a positive correlation between nitrates and TSH $(R=0.487, p=0.003)$ and a negative correlation between nitrates and FT4 $(R=-0.312, p=0.06)$. For the iron status, we found a negative correlation between nitrates and SF $(R=-0.429, p=0.009)$ and between nitrates and $\mathrm{Hb}(\mathrm{R}=-0.383, \mathrm{p}=0.021)$. The Mann-Whitney U-test showed that in women with nitrate levels higher than the mean value there was low FT4 level $(p=0.06)$, high TSH level $(p=0.013)$, low $\mathrm{Hb}$ concentration $(p=0.061)$ and low SF concentration $(p=0.005)$. The combined effects of environmental factors (elevated nitrate levels and low selenium level) on the iodine and iron status are manifested by low concentrations of FT4 $(p=0.033), \mathrm{Hb}(p=0.06)$ and SF $(p=0.05)$ and high level of TSH $(p=0.05)$.

In conclusion, we found that environmental factors, especially when combined, have a negative impact on the iron and iodine status of females.

\section{INTRODUCTION}

Agents provoking thyroid gland enlargement are known as strumogens (goitrogens). They may cause goiter by acting directly on the thyroid gland, but their action may also be indirect realized by altering the regulatory mechanisms of the thyroid gland and the peripheral metabolism and the thyroid hormones secretion. ${ }^{1}$

Cabbage, cauliflower, broccoli, turnips, millet, spinach, milk and some sorts of beans are the goitrogenic foods on Bulgaria. ${ }^{2}$ They contain cyanogenic glycosides which upon ingestion release cyanide that is subsequently metabolized to thiocyanate. ${ }^{3}$ Thiocyanates are powerful goitrogenic substances as they are anions with the same molecular size as the iodide ion. ${ }^{4}$ Smoking mothers present with significantly high serum levels of thiocyanates that inhibit competitively the sodium-iodide symporter (NIS) which is responsible for the iodide transport in both the thyroid and the mammary gland during lactation. Smoking during the breastfeeding period increases the risk of iodine deficiency and can cause brain damage in infants. ${ }^{5}$

Many foods and drinking-water contain nitrates, but fresh vegetables are their main source for the human organism. ${ }^{6}$ They can also be added as preservatives to foods such as meat and fish. ${ }^{7}$ Nitrates compete with iodine transport in the thyroid adversely affecting the function of the gland. ${ }^{8}$ Excess nitrite intake in infants causes oxyhemoglobin iron $\left(\mathrm{Fe}^{2+}\right)$ to oxidize to $\left(\mathrm{Fe}^{3+}\right)$ in methemoglobin. This 
leads to hypoxia and cyanosis. ${ }^{9}$

Selenium deficiency is especially dangerous during pregnancy when the demand for Se rises considerably due to the development of the fetus and the elevated tissue metabolism of the mother's organism. This issue, however, has been inadequately studied worldwide and much of the existing data is controversial at present. So far in Bulgaria, no systematic research has been conducted on this matter despite the fact that there are regions in the country with proven selenium deficiency, one of these being the Rhodope endemic region. ${ }^{10}$

Normally, there is a high concentration of $\mathrm{Se}$ in the thyroid gland even when there is severe dietary deficiency. The gland holds a large number of selenocysteine-containing enzymes such as glutathione peroxidases, thioredoxin reductases and deiodinases. ${ }^{11}$

\section{AIM}

The aim of this study was to find correlations between some environmental factors (between the high thiocyanate and nitrate levels and the low Se levels) and the indicators of iodine and iron status in a risk population group such as postpartum women.

\section{PATIENTS AND METHODS}

The study included 41 mothers (1-3 days after birth, age 26.4 $\pm 5.9 \mathrm{yrs}$ ) from Asenovgrad and nearby villages. The indicators of iron status $(\mathrm{Hb}$, SF, and sTfR) were used to assess their iron status. Their iodine status was assessed using the urinary iodine indicators, thyroxin and thyroid-stimulating hormone, and some environmental factors such as urinary thiocyanates, nitrates and serum selenium.

The study protocol was approved by the Ethics Committee of the Medical University in Plovdiv (resolution №4/18.07.2013), in accordance with the Declaration of Helsinki. Written informed consent was obtained from all participants in the study.

The study subjects completed appropriate questionnaires by using "yes" or "no" answers concerning their nutritional behavior, exposure to tobacco smoke, smoking habits, iodine intake from other sources (e.g., supplementary tablets), thyroid disorders, and underlying or chronic diseases.

Iodine concentration in urine was measured using the Sandell-Kolthoff reaction and is based on the recommendations of the International Council for the Control of Iodine Deficiency Disorders. ${ }^{12}$ ELISA for quantitative determination of TSH and free thyroxin (FT4) in human serum by Globe
Diagnostics, Italy was used for TSH and FT4 assessment. The blood $\mathrm{Hb}$ levels were measured using STKS Coulter Hematology Analyzer (USA) and Sysmex 9500 (Kobe, Japan). The SF and sTfR levels were determined with ELISA (BioVendor LLC, Czech Republic). Serum nitrates concentration was measured using a colorimetric method (Nitrate/ Nitrite Colorimetric Assay Kit, Cayman Chemical Company, USA). The assessment of thiocyanate concentration in urine is based on the interaction of thiocyanate ions with acidic solution of $\mathrm{KMnO}_{4}$ (potassium permanganate) at room temperature in a sealed test-tube, thereby releasing HCN (hydrogen cyanide). ${ }^{13}$ The amount of selenium was determined using electrothermal atomic absorption spectrophotometry.

\section{Statistical ANALYSiS}

One-Sample Kolmogorov-Smirnov D test and Shapiro-Wilk test were used to test the quantitative (variation) variables for normality. The difference between the mean values of the normally distributed quantitative variables (sTfR, TSH, FT4, Hb, thiocyanates, the selenium-nitrate) of two independent groups was evaluated by Student t-test and ANOVA test, and the Mann-Whitney (M-W) and Kruskal-Wallis tests were used for the comparison of variables with abnormal distribution (SF, iodine). Pearson's and Spearman's correlation analyses were applied depending on the index distribution. We used the statistical software package SPSS 17.0 for Windows (SPSS Inc.).

Differences with $\mathrm{p}<0.05$ were considered statistically significant.

\section{RESULTS}

\section{IODINE STATUS}

The effect on iodine status is shown through the correlations between thiocyanates and iodine in urine (Fig. 1a) and nitrates and TSH (Fig. 1b). The levels of nitrates and FT4 showed a tendency to be negatively correlated $((\mathrm{R}=-0.312, \mathrm{p}=0.06)$.

Low level of ioduria $(p=0.003)$ was found in $27.8 \%$ of the women with thiocyanates levels higher than the mean level $(3.13 \mathrm{mg} / \mathrm{L})$ versus in $2.8 \%$ of females with low thiocyanates levels.

Low FT4 levels (below the lower limit according to the manufacturing company, $9 \mathrm{pmol} / \mathrm{L}$ ) were found in $11.1 \%$ of the females with nitrates higher than the mean value $(19.67 \mu \mathrm{mol} / \mathrm{L})$, while these were found in $5.6 \%$ of females with low nitrates $(\mathrm{p}=0.05)$. 
The higher risk of low FT4 with high nitrates above the mean value $(\mathrm{OR}=6.57,95 \% \mathrm{CI} 0.99$ 43.78) is based on these results.

Selenium alone had no effect on the indicators of the iodine status $(\mathrm{p}=0.05)$.

\section{IRON STATUS}

Nitrates had an effect on the levels of ferritin (Fig.

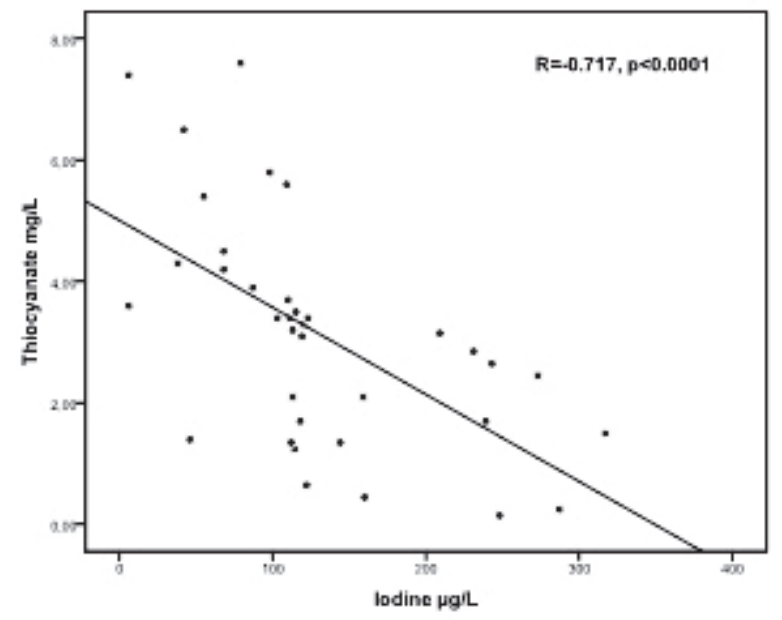

Figure 1a. Correlations between thiocyanates and urine iodine.

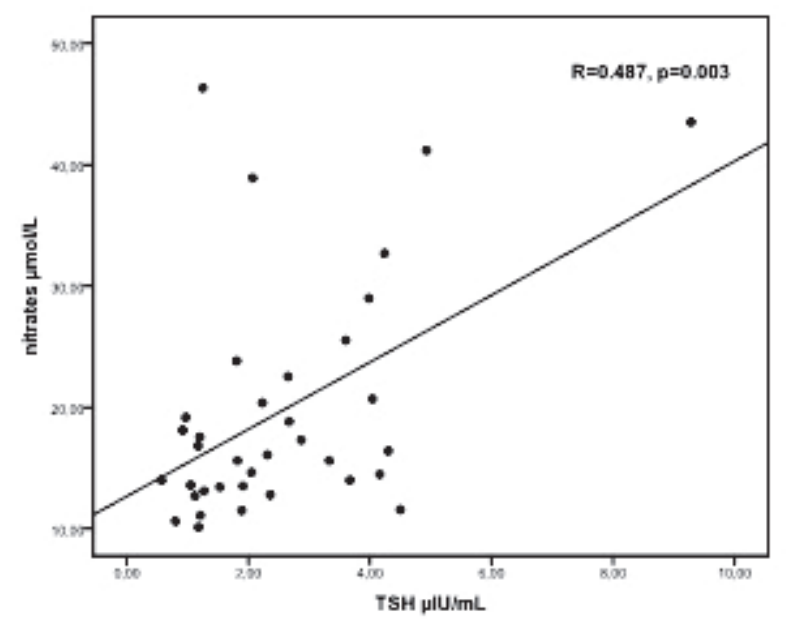

Figure 1b Correlations between nitrates and TSH.

2a) and $\mathrm{Hb}$ (Fig. 2b), but not on the level of sTfR $(\mathrm{R}=0.221, \mathrm{p}=0.196)$.

The study subjects were allocated into two groups according to their nitrate concentrations (high and low nitrates level groups) in relation to the mean value
$(19.67 \mu \mathrm{mol} / \mathrm{L})$. The $\mathrm{Hb}$ level in the high nitrates group was $98.73 \pm 18.94 \mathrm{~g} / \mathrm{L}$ versus $110.92 \pm 13.65 \mathrm{~g} / \mathrm{L}$ in the low nitrate group (mean $\pm \mathrm{SD})(\mathrm{p}=0.036)$. Ferritin in the women with high nitrate levels was median $4.97 \mathrm{ng} / \mathrm{mL}$ (95\% CI 1.38-18.1), while in the low nitrates group it was median $38.12 \mathrm{ng} / \mathrm{mL}$ (95\% CI 25.16-51.08) $(\mathrm{p}=0.005)$.

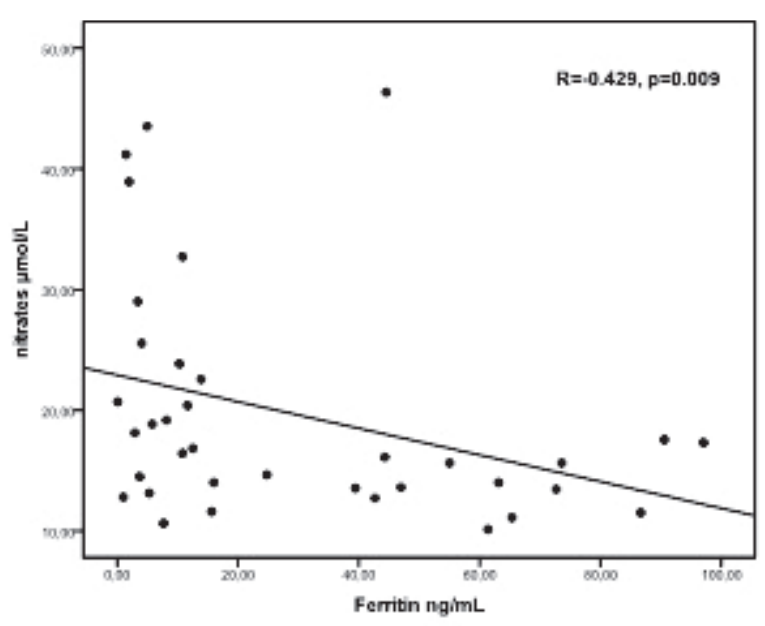

Figure 2a. Correlations between nitrates and ferritin.

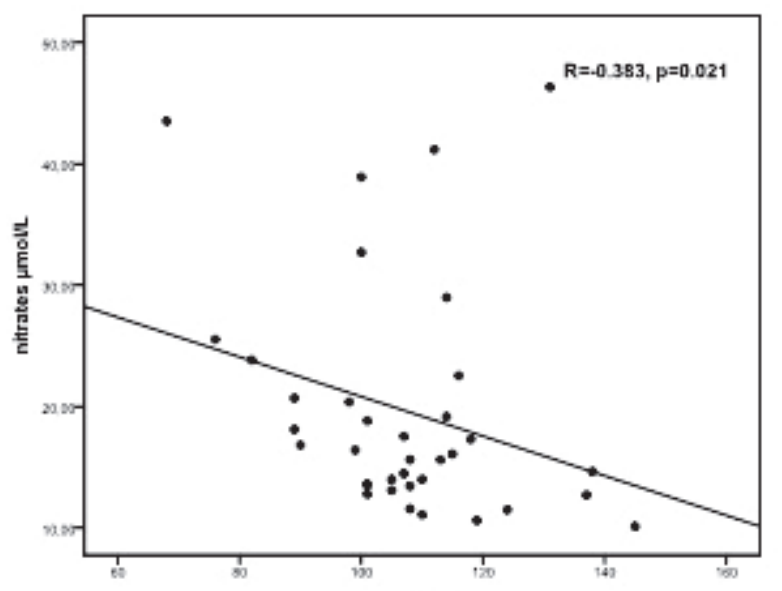

Figure 2b Correlations between nitrates and $\mathrm{Hb}$.

Of the females with thiocyanate levels higher than the mean value $(3.13 \mathrm{mg} / \mathrm{L}), 44.4 \%$ had low $\mathrm{Hb}$ levels (below $110 \mathrm{~g} / \mathrm{L}$ ), indicative of anemia in postpartum women ${ }^{2}$, versus $19.4 \%$ of the women with high $\mathrm{Hb}$ levels $(\mathrm{p}=0.014)$. 
The division of the females into two subgroups has proven that the simultaneous action of low selenium levels (below the mean value of 881.58 $\mu \mathrm{mol} / \mathrm{L}$ ) and high nitrate levels (above the mean value of $19.67 \mu \mathrm{mol} / \mathrm{L}$ ) demonstrates a statistically significant effect on the indicators of both the iodine and the iron status: lower levels of FT4, $\mathrm{Hb}$ and $\mathrm{SF}$, but a higher one for TSH (Table 1). to form carboxyhemoglobin $(\mathrm{COHb})$. Because $\mathrm{CO}$ has a hemoglobin-binding affinity that is $240-350$ times greater than that of oxygen, tobacco smoke inhalation readily leads to $\mathrm{COHb}$ formation. Carboxyhemoglobin impairs the transport of oxygen to tissues. In sufficient quantity, it will produce a functional anemia. ${ }^{19,20}$ This could account for the low hemoglobin level in women with high thio-

Table 1. Combined effect of low selenium levels and high nitrate levels on iodine and iron status indicators

\begin{tabular}{lcccc}
\hline & $\begin{array}{c}\text { Selenium<mean } \\
\text { Nitrates mean }\end{array}$ & $\begin{array}{c}\text { Selenium<mean } \\
\text { Nitrates<mean }\end{array}$ & p & test \\
\hline FT4 $(\mathrm{pmol} / \mathrm{L})$ & $8.41 \pm 1.96$ & $10.51 \pm 1.70$ & $0.036^{*}$ & $\mathrm{t}$-test \\
TSH $(\mathrm{mIU} / \mathrm{L})$ & $3.22 \pm 1.01$ & $2.05 \pm 0.96$ & $0.033^{*}$ & $\mathrm{t}$-test \\
Hb $(\mathrm{g} / \mathrm{L})$ & $97.6 \pm 13.66$ & $112.86 \pm 16.95$ & $0.089^{*}$ & $\mathrm{t}$-test \\
SF $(\mathrm{ng} / \mathrm{mL})$ & $4.05(95 \% \mathrm{CI} 0.78-11.97)$ & $43.48(95 \% \mathrm{CI} 21.82-58.56)$ & $0.05^{*}$ & $\mathrm{M}-\mathrm{W}$ \\
\hline
\end{tabular}

* statistical significance

\section{DISCUSSION}

Environmental contamination with various organic and inorganic chemical substances with a goitrogenic effect (nitrates, pesticides, thiocyanates, perchlorate, phenol etc.) has somehow an impact on the relative iodine deficiency or may suppress directly the synthesis of thyroid hormones. ${ }^{14,15}$ These chemical agents stimulate the manifestation and severity of iodine deficiency disorders in endemic iodine deficiency regions such as the Asenovgrad region in Bulgaria. Carrillo et al. argue that passive smoking disturbs thyroid function. ${ }^{16}$ In the present study we tried to find an association between ioduria as a reliable current iodine status indicator of the tested females, and the urinary thiocyanate concentration, which is most probably related to the exposure to tobacco smoke. According to WHO, the critical threshold of urinary iodine is $100 \mu \mathrm{g} / \mathrm{L} .{ }^{17}$ As typical Bulgarian cuisine lacks thiocyanate-rich foods, we assumed that nicotine smoke was the main source of urinary thiocyanates. The high percentage of women in the present study subjected to passive smoking (58.3\%) and active smokers $(22.2 \%)$ determines the strong statistical significant correlation between thiocyanates and ioduria $(p<0.0001)$ (Fig. $1 \mathrm{a})$, a finding consistent with the results of other researchers as well. ${ }^{18}$

Carbon monoxide (CO) is present in tobacco smoke. When it is inhaled it binds with hemoglobin cyanate levels in comparison to the group with a low thiocyanate level as established in our studies.

Nitrates in drinking-water and food are discussed as a provoking factor in the etiology of endemic goiter during iodine deficiency. ${ }^{8}$ In recent years, special attention has been devoted to their impact on vulnerable population groups - children and pregnant women ${ }^{21}$, yet postpartum women have not been studied. Our study proves a bilateral effect of high nitrate levels on both the iodine status (Fig. 1b) and the iron status (Fig. 2). High nitrate levels cause methemoglobinemia $\left(\mathrm{Fe}^{3+}\right)$. Methemoglobinemia usually results from exposure to oxidizing substances such as nitrates or nitrites. The iron within hemoglobin is oxidized from the ferrous to the ferric state, which blocks the transport of oxygen and carbon dioxide with subsequent inhibition of the respiratory chain. ${ }^{22}$ The exposure of mothers to nitrates can lead to anemia and premature birth. ${ }^{23}$

Several trace elements are essential for normal thyroid hormone metabolism - iodine, iron, selenium, zinc. Coexisting deficiencies of these elements can impair the thyroid function. ${ }^{24}$ Thyroid peroxidase participates in the initial stages of thyroid hormone synthesis. This enzyme contains a heme in its active center and therefore requires iron. ${ }^{25}$

Normally, the thyroid gland contains a high concentration of selenium even during selenium 
deficiency. Many of the well-known selenocysteinecontaining enzymes - glutathione peroxidase, deiodinase and thioredoxin-reductase, are expressed in the gland. ${ }^{24}$ Glutathione peroxidases reduce hydroperoxides through reducing equivalents from reduced glutathione. Iodothyronine deiodinases remove iodine from the thyroid hormones (T4, T3) in the metabolism of the active hormone - T3. Thioredoxin reductases are NADPH-dependent flavoenzymes that function in intracellular redox regulation by reducing thioredoxin..$^{26,27}$ Despite the fact that many mechanisms regulate the synthesis of deiodinases (TSH, the thyroid hormones, cAMP), the Se content directly affects their activity as well, therefore affecting indirectly the synthesis of T3. ${ }^{28}$ Thus, selenium deficiency can enhance the presence of iodine deficiency. ${ }^{29}$

Selenium deficiency is a current issue and is insufficiently explored worldwide. A study in China shows that low selenium status is associated with an increased risk of thyroid disease. Increased selenium intake may reduce the risk in areas of low selenium intake that exist not only in China, but also in many other parts of the world. ${ }^{30} \mathrm{~A}$ few studies on the subject have been conducted in our country ${ }^{10,31}$, showing that Bulgaria is amongst the countries with lowest selenium content in the soil, which results in its low intake through food and drinking-water by our population.

A study of Nepali children shows a negative correlation between the selenium and ferritin serum levels $(p<0.05)^{32}$, while our results from the breastfeeding women research did not show any correlation between those two indicators $(p>0.05)$.

We looked for an effect of the combined influence on the increased serum nitrates level and the low level of serum selenium on the iodine and iron status in women. It is expressed as a statistically significantly low FT4 $(\mathrm{p}=0.033)$, high TSH $(p=0.05)$, low $\mathrm{Hb}(\mathrm{p}=0.06)$ and low SF $(p=0.05)$ (Table 1). Our study shows that the low selenium level alone does not affect these indicators $(\mathrm{p}>0.05)$, but amidst increased nitrates, the changes turn out to be significant.

Most studies in literature are focused on the independent effect of micronutrient deficiencies or on other combinations of environmental factors, as opposed to the indicators of the iodine and iron status. ${ }^{15} \mathrm{We}$ are not aware of a similar study in our scientific literature, focused on the simultaneous impact of several goitrogenic factors, which involves vulnerable population group such as postpartum women, as well as their impact in terms of iron status indicators.

\section{CONCLUSION}

Environmental factors - high levels of thiocyanates, nitrates and low levels of selenium, especially when combined, have a negative impact on iron and iodine status of postpartum women. High thiocyanate levels lower the levels of iodine in urine and $\mathrm{Hb}$. High nitrate levels elevate TSH, but lower FT4, $\mathrm{SF}$ and $\mathrm{Hb}$.

\section{CONFLICT OF INTEREST}

None of the authors report any conflict of interest.

\section{REFERENCES}

1. Gaitan E, Goitrogens in Food and Water. Annu Rev Nutr 1990;10:21-39.

2. Ivanova L. Strategies for control of micronutrient deficiencies. The Science of nutrition in relation to human health preservation. Popov B. editor; Sofia: Blenda Publishing; 2004, 204-213 (Bulgarian).

3. Vetter J. Plant, Cyanogenic Glycosides. Toxicon 2000;38(1):11-36.

4. Tonacchera M, Pinchera A, Dimida A, et al. Relative potencies and additivity of perchlorate, thiocyanate, nitrate, and iodide on the inhibition of radioactive iodide uptake by the human sodium iodide symporter. Thyroid 2004;14:1012-9.

5. Das S, Bhansali A, Dutta P, et al. Persistence of goiter in the post-iodization phase: micronutrient deficiency or thyroid autoimmunity? Indian J Med Res 2011;133:103-9.

6. National plan of action: Food and nutrition 20052010. Information system for data survey on nutrition, nutritional status and health issues, related to nutrition of Bulgarian population, page 25 (Bulgarian).

7. Mervish N, Blount B, Valentin-Blasini L, et al. Temporal variability in urinary concentrations of perchlorate, nitrate, thiocyanate and iodide among children. J Expo Sci Env Epid 2012;22:212-218.

8. WHO. Nitrate and Nitrite in Drinking water. Background document for development of WHO Guidelines for drinking water Quality. WHO, Geneva, Switzerland. 2011.

9. McKnight G, Duncan C, Leifert C, Golden M. Dietary nitrate in man: friend or foe? Br J Nutr 1999;81:349-58.

10. Lozanov B, Tsachev K, Kirilov G, et al. [Serum concentration of selenium and thyroid status of postpartum women during systematic iodine prophylactics.] Endocrinology 2008;13(2):56-64 (Bulgarian). 
11. Beckett G, Arthur J. Selenium and endocrine systems. J Endocrinol 2005;184(3):455-65.

12.Dunn J, Crutchfield H, Gutekunst R, et al. Methods for measuring iodine in urine. A joint publication of ICCIDD, UNICEF and WHO, Wageningen, The Netherlands, WHO. 1993;18-51.

13. Haque M, Bradbury J. Simple method for determination of thiocyanate in urine. Clin Chem 1999;45(9):1459-1464.

14. Haque M, Bradbury J. Simple method for determination of thiocyanate in urine. Clin Chem 1999;45(9):1459-1464.

15. Horton M, Blount B, Valentin-Blasini L, et al. COoccurring exposure to perchlorate, nitrate and thiocyanate alters thyroid function in healthy pregnant women. Environ Res 2015;143(Pt A):1-9.

16.Horton M, Blount B, Valentin-Blasini L, et al. COoccurring exposure to perchlorate, nitrate and thiocyanate alters thyroid function in healthy pregnant women. Environ Res 2015;143(Pt A):1-9.

17. Marwaha R, Gopalakrishnan S. Facts of iodine supplementation. J Assoc Physicians India 2011;59 Suppl:7-10.

18. Czarnywojtek A, Kurdybacha P, Florek E, et al. Smoking and thyroid diseases - what is new? Przegl Lek 2010;67(10):1056-1060.

19. Hill P, Haley N, Wynder E. Cigarette Smoking: Carboxyhemoglobin, Plasma Nicotine, Cotinine and Thiocyanate vs. Self-Reported Smoking Data and Cardiovascular Disease. J Chron Dis 1983; 36:439-49.

20. Nedkova V, Angelova M, Milanova V, et al. [Smoking in children with asthma.] Science Pulmonology 2011;4:147-150 (Bulgarian).

21. Hartoft-Nielsen M-L, Boas M, Bliddal S, et al. Do Thyroid Disrupting Chemicals Influence Foetal Development during Pregnancy? J Thyroid Res 2011;2011:342189.

22.Lindenmann J, Fink-Neuboeck N, Schilcher G, et al. Severe methemoglobinemia treated with adjunctive hyperbaric oxygenation. Diving Hyperb Med 2015;45(2):132-4.

23. Agency for Toxic Substances and Disease Registry. (2011, January). Nitrates and nitrites. Division of Toxicology and Environmental Medicine ToxFAQs. Retrieved from http:/www.atsdr.cdc.gov/toxfaqs/ tf.asp?id=1186\&tid=258.

24.Zimmermann MB, Köhrle J. The impact of iron and selenium deficiencies on iodine and thyroid metabolism: biochemistry and relevance to public health. Thyroid 2002;12:867-78.

25. Gärtner, R. Essential trace elements for the thyroid: the importance of iodine, selenium and iron for normal thyroid function. Prevention und Gesundheitsforderung 2007;2(3):185-90.

26. Köhrle J. Selenium and the thyroid. Curr Opin Endocrinol Diabetes Obes 2013;20:441-8.

27. Combs GF Jr. Biomarkers of selenium status. Nutrients 2015;7(4):2209-36.

28. Drutel A, Archambeaud F, Caron P. Selenium and the Thyroid Gland. Clin Endocrinol 2013;78(2):155-64.

29. Triggiani V, Tafaro E, Giagulli VA, et al. Role of iodine, selenium and other micronutrients in thyroid function and disorders. Endocr Metab Immune Disord Drug Targets 2009;9(3):277-94.

30. Wu Q, Rayman M, Lv H, et al. Low Population Selenium Status Is Associated With Increased Prevalence of Thyroid Disease. J Clin Endocrinol Metab 2015;100(11):4037-47.

31. Vladeva S. Diabetes mellitus and microelements - experimental and clinical studies. [PhD Thesis] Plovdiv, Bulgaria, Medical University of Plovdiv, 2004 (Bulgarian).

32. Schulze K, Christian P, Wu L, et al. Micronutrient deficiencies are common in 6-to-8-year-old children of rural Nepal, with prevalence estimates modestly affected by inflammation. J Nutr 2014;144 (6):979-87. 


\title{
Влияние нитратов, тиоцианатов и селена на уровень железа и йода У рожениц
}

\author{
Анелия В. Биволарска' ${ }^{1}$ Анна И. Манева' ${ }^{1}$ Пенка Д. Гацева², Мариана Н. Кацарова' \\ ${ }^{1}$ Кафедра химии и биохимии, Факультет фармацевтики, Пловдивский медицинский университет, Пловдив, Болгария \\ 2 Кафедра гигиены и экомедицины, Факультет общественного здоровья, Пловдивский медицинский университет, Плов- \\ див, Болгария
}

\section{Для корреспонденции: Анелия Биволарска, Кафедра химии и биохимии, Факультет фармацевтики, Пловдивский медицинский университет, Пловдив, Болгария \\ E-mail: anellena@abv.bg тел. +35932602545, 0887611786}

Дата получения: 04.11.2015 г. Дата приемки: 31.05.2016 г. Дата онлайн публикации: 08.08.2016 г.

Дата публикации: 30.09.2016 г.

Ключевые слова: йод, нитраты, тиоцианаты, уровень железа, уровень йода

Цитаты: Биволарска А.В., Манева А.И., Гацева П.Д., Кацарова М.Н. Влияние нитратов, тиоцианатов и селена на уровень железа и йода у рожениц.

Журнал "Folia Medica" 2016;58(3);188-194; doi: 10.1515/folmed-2016-0024
Цель: Целью настоящего исследвания является установление корреляционной зависимости между высокими уровнями тиоцианата и нитрата и низкими уровнями селена по сравнению с показателями уровня йода и железа у женщин в послеродовом периоде.

Материалы и методы: Было проведено исследование 41 матери в возрасте 26.4 г土5.9, являющихся уроженками города Асеновграда и близлежащих сел. Наличие йода в моче было выявлено с помощью реакции Санделла-Кольтхофа, наличие тиоцианатов - путем взаимодействия ионов с кислым раствором $\mathrm{KMnO} 4$, сывороточный уровень нитратов - с помощью колориметрического метода, наличие сывороточного селена - с помощью электротермической атомно-абсорбционной спектрофотометрии, наличие тироксина (FT4), тиреостимулирующего гормона (TSH), сывороточного феритина (SF), сывороточного трансферринового рецептора (sTfR) - с помощью метода ELISA; гемоглобина (Hb) - с помощью гематологического анализа.

Результат: Относительно уровня йода выявлена негативная корреляция со статистическим значением между уровнями йода и тиоцианатов в моче $(\mathrm{R}=-0.717, \mathrm{p}<0.0001)$, положительная корреляция между нитратами и TSH $(\mathrm{R}=0.487, \mathrm{p}=0.003)$ и негативная корреляция между нитратами и FT4 $(\mathrm{R}=-$ $0.312, p=0.06)$. Относительно уровня железа выявлена негативная корреляция между нитратами и SF ( $R=-0.429, p=0.009)$, а также между нитратами и $\mathrm{Hb}$ $(\mathrm{R}=-0.383, \mathrm{p}=0.021)$. Тест Манна-Уитни показал, что в группе женщин с уровнем нитратов, превышающим средний показатель, наблюдается более низкий FT4 $(p=0.06)$, более высокий TSH ( $p=0.013)$, более низкий Нb $(p=0.061)$ и более низкий SF ( $p=0.005)$. Комбинированное влияние факторов окружающей среды (повышенные уровни нитратов и низкий уровень селена) на уровень йода и железа выражается в более низком уровне FT4 со статистическим значением $(p=0.033)$, более высоком TSH $(p=0.05)$, более низком Hb $(p=0.06)$, более низком SF ( $p=0.05)$.

Заключение: Было установлено, что факторы окружающей среды, особенно когда комбинируются, оказывают негативное влияние на уровень железа и йода у женщин. 